\title{
Faunal Variation on Pelagic Sargassum
}

\author{
Michael L. Fine \\ College of William and Mary - Virginia Institute of Marine Science
}

Follow this and additional works at: https://scholarworks.wm.edu/etd

Part of the Marine Biology Commons, and the Oceanography Commons

\section{Recommended Citation}

Fine, Michael L., "Faunal Variation on Pelagic Sargassum" (1969). Dissertations, Theses, and Masters Projects. Paper 1539617420.

https://dx.doi.org/doi:10.25773/v5-bn07-7987

This Thesis is brought to you for free and open access by the Theses, Dissertations, \& Master Projects at W\&M ScholarWorks. It has been accepted for inclusion in Dissertations, Theses, and Masters Projects by an authorized administrator of W\&M ScholarWorks. For more information, please contact scholarworks@wm.edu. 
FAUNAL VARIATION ON

PELAGIC SARGASSUM

A Thesis

Presented to

The Faculty of the School of Marine Science

The College of William and Mary in Virginia

In Partial Fulfillment

Of the Requirements for the Degree of

Master of Arts

By

Michael L. Fine

1969 


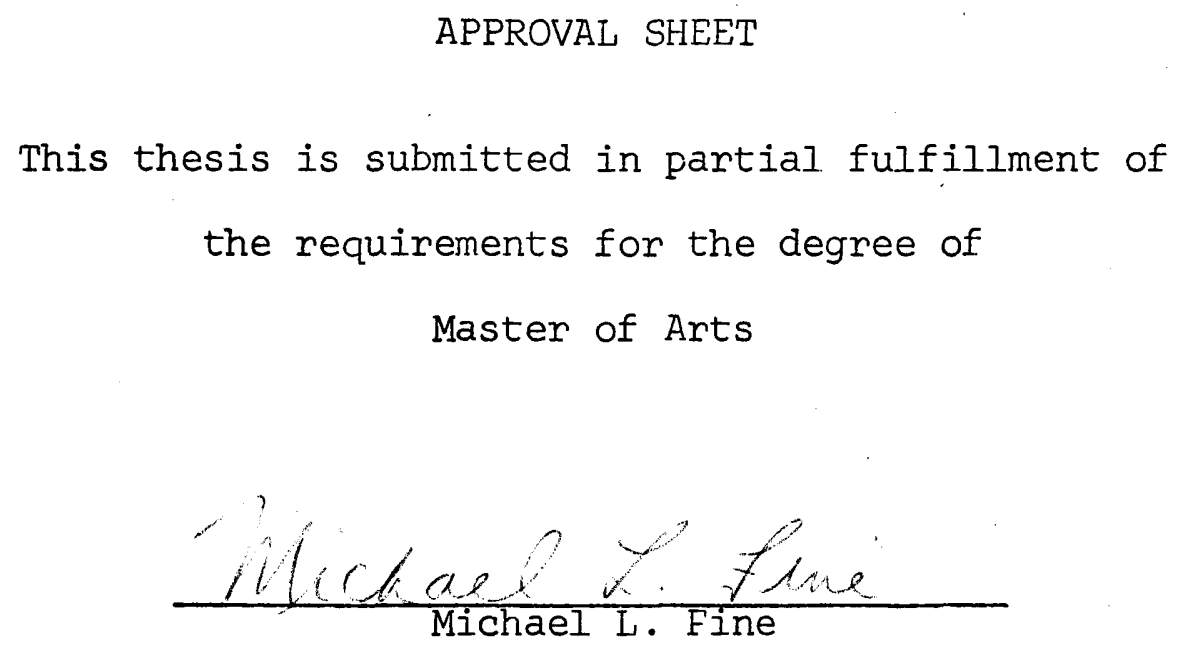

Approved, December 1969

$\frac{\text { Pharrin } \$ 2 \text { Caze }}{\text { Marvin L. Wass, Ph.D. }}$

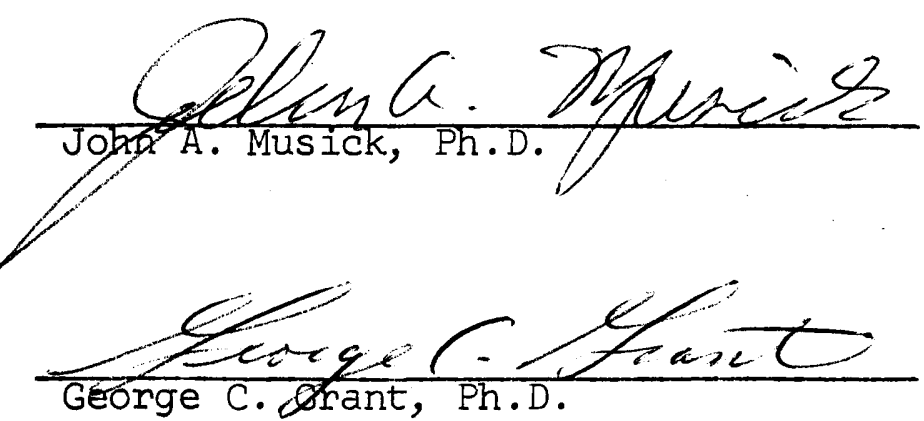




\section{ACKNOWLEDGMENTS}

I wish to express my sincere appreciation to Doctors Marvin L. Wass, John A. Musick, and George C. Grant who guided and criticized this study. In addition Messrs. Richard G. Swartz and Donald F. Boesch and Dr. Mark E. Chittenden gave freely of their knowledge, often at critical times. Miss Sarah B. Leonard and Mr. Donald F. Boesch respectively donated the early and late spring samples used in this study. The Sargassum was collected aboard the R. V. Eastward of Duke University and the National Aeronautics and Space Administration vessel Range Recoverer.

This thesis was immensely aided by many people who helped me identify species from various animal taxa: Adrian R. Lawler, Polycladida, VIMS; Dr. David R. Franz, Nudibranchia, University of Connecticut, Storrs, Connecticut; Dr. John C. McCain, Caprellidae, USNM, Smithsonian Institution, Washington, D. C.; James K. Lowry, Gammaridea and Hyperidae, University of Canterbury, Christchurch, New Zealand; Dr. Morris H. Roberts, Jr., decapod larvae, Providence College, Providence, Rhode Island; Dr. George C. Grant, Chaetognatha, VIMS; and John D. McEachran and Dr. John A. Musick, Osteichthyes, VIMS. 
TABLE OF CONTENTS

Page

ACKNOWLEDGMENTS . . . . . . . . . . . . . . . . . . . . iii

LIST OF TABLES . . . . . . . . . . . . . . . . . . . . V v

LIST OF FIGURES . . . . . . . . . . . . . . . . . . . . . . vi vi v v

ABSTRACT . . . . . . . . . . . . . . . . . . . . . vii

INTRODUCTION . . . . . . . . . . . . . . . . . . . . 2

MATERTALS AND METHODS . . . . . . . . . . . . . . . . 6

RESULTS . . . . . . . . . . . . . . . . . . . . . . 11

DISCUSSION . . . . . . . . . . . . . . . . . . . 18

LITERATURE CITED . . . . . . . . . . . . . . . . . . 33 
Table

1. Position and surface temperature where Sargassum samples were collected and respective raft volumes . . . . . . . . . . . . . . . . .

2. Number of species and individuals, diversity and equitability of Sargassum samples . . . . . . . 12

3. Faunal frequency evaluation of Area I . . . . . . . . 24

4. Faunal frequency evaluation of Area II . . . . . . . 25

5. Faunal frequency evaluation of Area III . . . . . . . 27

6. Faunal frequency evaluation of $R R 20$. . . . . . . . 29

7. Faunal frequency evaluation of Series S . . . . . . 30

8. Faunal frequency evaluation of Series D . . . . . . 32 


\section{LIST OF FIGURES}

Figure

Page

1. Location of stations where Sargassum was

collected . . . . . . . . . . . . . . . .

2. Relationship of diversity $\left(\mathrm{H}^{\dagger}\right)$ to raft

volume for all samples . . . . . . . . . . . .

3. Relationship of the number of individuals

to raft volume for samples collected during

the spring and late summer . . . . . . . . . . . 15

4. Trellis diagram of the dominance affinity index

for all sample pairs . . . . . . . . . . . . 16 


\section{ABSTRACT}

Pelagic Sargassum was collected in late summer, late winter, and early and late spring from inshore waters, the Gulf stream and the Sargasso Sea of the Western North Atlantic Ocean. The noncolonial macrofauna was picked from the weed samples. The 34 samples contained 67 species and 11,234 individuals. The Shannon-Wiener index of diversity had a mean value of $2.510 \pm 0.247\left(t_{.05} s_{\bar{x}}\right)$ and a statistical range between 1.093 and 3.927 ( $t_{.05} s$ ). Mean diversity values were not significantly different among the various sampling series and diversity did not vary with raft volume. High diversity values were related to an equitable distribution of species resulting frorn a stable environment and an area low in productivity. Species composition of the Sargassum organisms varied seasonally and geographically. Animals were more abundant in the spring than in the fall samples. Samples collected on a transect in the Gulf Stream and Sargasso sea maintained a similar faunal composition. 
FAUNAL VARIATION ON

PELAGIC SARGASSUM 


\section{INTRODUCTION}

The brown alga Sargassum, or gulf-weed, belongs to the order Fucales which contains many species with vesicles or bladders for buoyancy. The presence of pelagic Sargassum with its attendant fauna is well known in the Sargasso Sea of the htlantic Ocean, but also occurs around Japan (Ida, Hiyama, and Kusaka, 1967) and in the Red Sea (Markkaveeva, 1965) with an associated fauna.

Winge (1923) and Deacon (1942) have reviewed the early literature on Sargassum. Krlimmel (1891) attempted to fix the boundaries of the Sargasso sea by studying the distribution of Sargassum. From records kept by German sea captains, he computed the number of times the weed was sighted in $1^{\circ}$ squares and then incorrectly combined his results to give $10 \%$, $5 \%$, and $0.3 \%$ probability contours for $5^{\circ}$ squares. Winge (1.923) collected Sargassum by plankton net and charted approximate boundaries of occurrence of the weed. Parr (1939) sampled extensive areas of the Sargasso Sea and the Gulf of Mexico and found that the sterile eupelagic species Sargassum natans and $\underline{S}$. fluitans made up over $99 \%$ of the total pelagic vegetation in the Sargasso sea and that the two morphological types natans I and fluitans III composed between 88 and $99 \%$ of this total. Other forms of natans and fluitans were correspondingly rare, and specjes torn from littoral bottoms were insignificant. From a variety of evidence Parr proved that attached coastal species, although occasionally encountered in the Gulf Strean, make no significant contribution to the flora of the 
Parr's work on vertical distribution of the weed demonstrated that only insignificant amounts are found below the surface. These results, buttressed by woodcock's (1950) study of the extreme buoyancy of Sargassum, prove further that the weed is in its natural. habitat on the high seas and is not a coastal castaway with a short pelagic life.

Life associated with Sargassum divides into a myriad of forns including micro-, meio-, and macrofaunal components. Conover and Sieburth (1964) and Sieburth and Conover (1965) worked on the bacteriocidal effects of Sargassum tannins on vibrios and pseudomonads isolated from the alga. With few exceptions the meiofauna is unstudied. Thulin (1942) found a tardigrade, Styraconyx sargassi, and Yeatman (1962) investigated the copepods of gulf-weed and hypothesized that the alga was the agent responsible for transplanting several American species to Europe. A cursory giance at the material. filtered from water in which the weed was agitated, revealed copepods, nematodes, anphipods, isopods, mites, and tardigrades.

Both sessile and motile forms compose the macrofauna. Many of the sessile species are colonial and in the case of hydroids, often specific for different morphological types of Sargassum (Winge, 1923; Burkenroad, in Parr, 1939; Weis, 1968). Hentschel. (1922) found changes in presence or absence of sessile species on different samples and attempted to quantify these species by the number of colonies O:- the number of vertical branches of hydroid on Sargassum leaves 10 on long. Hentschel analyzed the gut's of the important sessile forms (Membranipora, Spironbis, Lepas, and Diploscral ) and discovered that these species subsisted largely on nannoplankton. Surprisingly, mariy of the guts contained nematocysts from Physalia and unidentified 
coelenterates. He attributed absence of food contents in hydroids to regurgitation caused by their preservation in formalin. After looking at the gut contents of the nudibranch Scyllaea pelagica and the grapsid crab Planes minutus, he concluded that the sessile organisms were not an important component of their food. Hentschel also discussed reproduction of the attached forms and described differences between the fauna of coastal and pelagic species.

Although Thomson (1878) and Murray and Hjort (1912) mention weed animals they encountered during their cruises, Timmermann (1932), a student of Hentschel, has done the only extensive work concerning motile forms. Unfortunately he attempted to cover the whole Sargasso Sea with 55 samples, many of which were small and sporadically distributed. Timmermann stated that the free living animals were saved in only some of the samples, but that the remainder sufficed, in general, to recognize the characteristic features of the goographical distribution. His species list appears to be low in numbers of individuals and numbers of species. I believe that his samples are unrepresentative, and I cannot accept his discussion of distribution and his observation of a decrease in fauna during the winter.

Prat (1935) discussed some of the animals and algae he found on Sargassum but gave no quantitative or station data. Adams (1960) described the postlarval development of the Sargassum fish Histrio histrio. Her paper ends with a discussion of the Sargassum complex from the Iiterature and a rather Iarge, though sourceless, list of species found on Sargassum. Weis (1968) dipped four samples of gulf-weed from the GuIf Stream and identified the animals to genus. She found large numbers of the shallow water snails Bittium and Rissoa 
on the weed but unfortunately chose to explain their presence by suggesting a benthonic origin for the sargassum. Winds at times pile up great masses of weed on beaches of the Atlantic and Gulf coasts. A change in wind direction will carry the weed back out to sea along with any newly recruited species, even intertidal forms. Available literature does not give more than a vague idea of the numerical distribution of organisms in the pelagic Sargassum community. My approach was to take a detailed look at that part of the Sargassum macrofauna which could be readily counted. Variations in time and space could then be charted with some confidence and indices of community ecology applied. 


\section{MATERIALS AND METHODS}

Sargassum samples were dip-netted in the Atlantic Ocean at a number of stations. I took 18 late summer samples between 1 and 5 October 1968 in three areas surrounding Cape Hatteras. Four of the samples came from north of the cape (I), five adjacent to the cape (II), and the remaining nine to the south (III). All further samples were taken south of Hatteras. On a late winter cruise in March (RR), I managed to obtain only one small sprig of Sargassurn in a plankton tow $\left(33^{\circ} 27^{\circ} \mathrm{N}, 76^{\circ} 56^{\circ} \mathrm{W}\right.$, temperature of $22.3 \mathrm{C}$, and volume of $\left.1.3 \mathrm{ml}\right)$. Scientists in an ainplane, looking for fish shoals, did not detect Sargassum north of Charleston, South Carolina. Nine early spring samples from April 29 of the previous year (S) came from a limited area within the Gulf stream. Late spring samples from 25 and 26 May 1969 (D) were collected along a transect from the Gulf Stream into the Sargasso sea. All samples were collected within a temperature range of 22 to $28^{\circ} \mathrm{C}$. Figure 1 shows a chart of the stations and Table 1 lists the position, temperature, and raft volume for each sample. Samples were preserved in 1.0\% buffered formalin and later picked for countable animals. All motile forms of approximately $1 \mathrm{~mm}$ and larger were selected as were the noncolonial sessile forms. The calcareous polychaete Spirorbis was not considered. Raft volumes were quantified by water displacement.

The arganisns were identified to species when possible. Identification of portunid crabs in the late sumrner samples presented a problem because both 


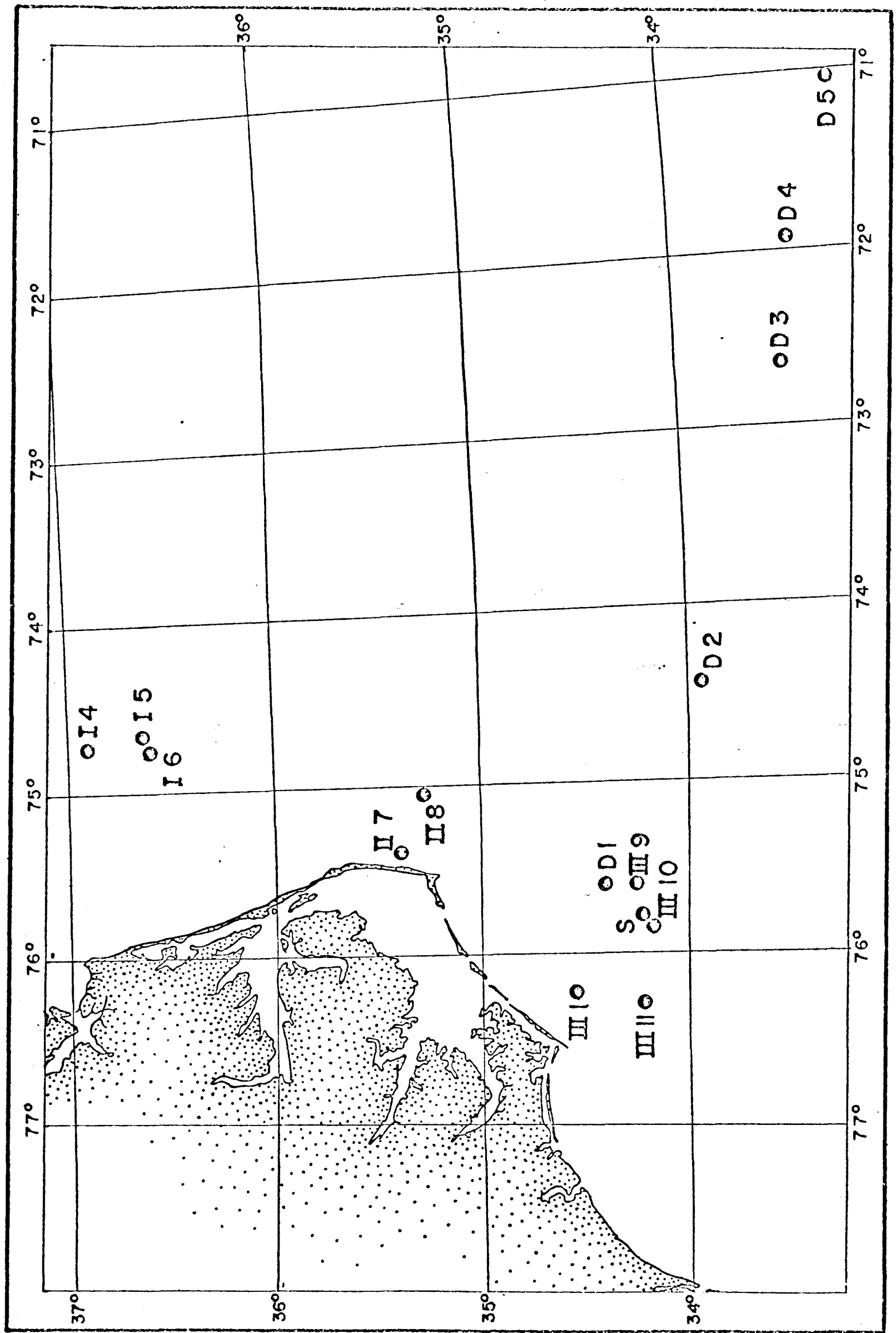


Table 1. Position and surface temperature where Sargassum samples were collected and respective raft volumes.

\begin{tabular}{|c|c|c|c|c|}
\hline Sample & $\begin{array}{c}\text { Latitude } \\
\text { North }\end{array}$ & $\begin{array}{c}\text { Longitude } \\
\text { West }\end{array}$ & $\begin{array}{c}\text { Temperature } \\
{ }^{\circ} \mathrm{C}\end{array}$ & $\begin{array}{c}\text { Raft Volume } \\
\text { ml. }\end{array}$ \\
\hline I 4 & $36^{\circ} 55^{\circ}$ & $74^{\circ} 44^{\prime}$ & 21.9 & 15 \\
\hline I 5 & $36^{\circ} 38^{\prime}$ & $74^{\circ} 42^{\prime}$ & 22.6 & 255 \\
\hline I $5 a$ & $36^{\circ} 38^{\prime}$ & $74^{\circ} 42^{\prime}$ & 22.6 & 151 \\
\hline I 6 & $36^{\circ} 37^{\circ}$ & $74^{\circ} 44^{\circ}$ & 22.3 & 325 \\
\hline II 7 & $35^{\circ} 24^{\prime}$ & $75^{\circ} 23^{\prime}$ & 23.6 & 82 \\
\hline II $7 a$ & $35^{\circ} 24^{\prime}$ & $75^{\circ} 23^{\prime}$ & 23.6 & 74 \\
\hline II $7 \mathrm{~b}$ & $35^{\circ} 24^{i}$ & $75^{\circ} 23^{\prime}$ & 23.6 & 242 \\
\hline II $7 c$ & $35^{\circ} 24^{\prime}$ & $75^{\circ} 23^{\circ}$ & 23.6 & 2.02 \\
\hline II 8 & $35^{\circ} 18^{\circ}$ & $75^{\circ} 03^{\prime}$ & 25.0 & 322 \\
\hline III I & $34^{\circ} 35^{\prime}$ & $76^{\circ} 14^{\circ}$ & 27.4 & 708 \\
\hline III la & $34^{\circ} 35^{\prime}$ & $76^{\circ} 14^{\prime}$ & 27.4 & 25 \\
\hline III 9 & $34^{\circ} 18^{\circ}$ & $75^{\circ} 37^{\prime}$ & 27.7 & 339 \\
\hline III $9 \mathrm{a}$ & $34^{\circ} 18^{\prime}$ & $75^{\circ} 37^{\circ}$ & 27.7 & 387 \\
\hline III 10 & $34^{\circ} 14^{\prime}$ & $75^{\circ} 51^{\prime}$ & 26.6 & 562 \\
\hline III $10 a$ & $34^{\circ} 14^{\prime}$ & $75^{\circ} 51^{\prime}$ & 26.6 & 817 \\
\hline III $10 \mathrm{~b}$ & $34^{\circ} 14^{\circ}$ & $75^{\circ} 51^{\prime}$ & 26.6 & 1327 \\
\hline III $10 \mathrm{C}$ & $34^{\circ} 14^{\prime}$ & $75^{\circ} 51^{\prime}$ & 26.6 & 424 \\
\hline III 11 & $34^{\circ} 16^{\circ}$ & $76^{\circ} 17^{\circ}$ & 27.5 & 388 \\
\hline$S 1$ & $34^{\circ} 16^{\prime}$ & $75^{\circ} 48^{\prime}$ & 23.0 & 157 \\
\hline$S 2$ & $34^{\circ} 16^{\circ}$ & $75^{\circ} 48^{\circ}$ & 23.0 & 64 \\
\hline$S 3$ & $34^{\circ} 16^{\circ}$ & $75^{\circ} 48^{\prime}$ & 23.0 & 71 \\
\hline$S 4$ & $34^{\circ} 16^{\prime}$ & $75^{\circ} 48^{\prime}$ & 23.0 & 40 \\
\hline$S 5$ & $34^{\circ} 16^{\prime}$ & $75^{\circ} 48^{\circ}$ & 23.0 & 38 \\
\hline S 6 & $34^{\circ} 16^{\prime}$ & $75^{\circ} 48^{\prime}$ & 23.0 & 30 \\
\hline S 7 & $34^{\circ} 16^{\prime}$ & $75^{\circ} 48^{\prime}$ & 23.0 & 33 \\
\hline S 8 & $34^{\circ} 16^{\prime}$ & $75^{\circ} 48^{\circ}$ & 23.0 & 20 \\
\hline S 9 & $34^{\circ} 16^{\prime}$ & $75^{\circ} 48^{\prime}$ & 23.0 & 13 \\
\hline D 1 & $34^{\circ} 21^{\prime}$ & $75^{\circ} 36^{\prime}$ & 26.2 & 102 \\
\hline D Ia & $34^{\circ} 21^{\prime}$ & $75^{\circ} 36^{\prime}$ & 26.2 & 127 \\
\hline D 2 & $33^{\circ} 56^{\prime}$ & $74^{\circ} 27^{\prime}$ & 21.6 & 92 \\
\hline D 3. & $33^{\circ} 32^{\circ}$ & $72^{\circ} 37^{\circ}$ & 21.8 & 124 \\
\hline D 4 & $33^{\circ} 26^{\prime}$ & $71^{\circ} 56^{\circ}$ & 22.1 & 134 \\
\hline D 5 & $33^{\circ} 15^{\circ}$ & $71^{\circ} 01^{\prime}$ & 22.2 & 269 \\
\hline
\end{tabular}


megalopa and juveniles were present. The larval forms were designatsd by letter (Portunid a, b, etc.), but the juveniles were only partially separated, resulting in the lumped category of Portunus spp. Many of the juveniles had autotomized their chelae, a structure needed for identification. In addition there was undoubtedly overlap between megalopa and juvenile forms. Statistical treatment of the portunids varied and will be explained in each case.

Diversity was calculated from Shannon's equation (1948) with the aid of tables provided by Lloyd, Zar, and Karr (1968). The diversity index $\left(\mathrm{H}^{\prime}\right)$ is based on the proportion of the number of individuals of each species to the total number of individuals in the sample:

$$
\begin{aligned}
& \mathrm{H}^{\prime}=-\Sigma \mathrm{p}_{i} \log _{2} \mathrm{p}_{i} \\
& \text { where } \mathrm{p}_{i}=\mathrm{n}_{i} / \mathrm{N} \\
& \mathrm{n}_{\mathrm{i}}=\text { number of individuals in the } i t h \text { species } \\
& \mathrm{N}=\text { total individuals in the sample. }
\end{aligned}
$$

This index is sensitive to both numbers of species and their distribution.

Equitability (E) (Lloyd and Ghelardi, 1964) specifically isolates the evenness of species distribution by comparing the number of species in a given sample to the number predicted by a hypothetical standard of species distribution, in this case MacArthur's (1957) model based on nonoverlapping niches:

$$
E=s^{i} / s
$$

where $s^{i}=$ the number of species conforming to MacArthur's model which would give the observed value for species diversity $s=$ the number of species present in the sample. When larval and juvenile portunids occurred in the same sample, 
inoividual categories of megalopa and juveniles were arbitrarily paired until the smalier category of the two was exhausted. For example, if four Portunid b megalopa, four Portunus sayi and five P. anceps occurred together, they would be treated as one species of eight organisms and a second species of five organisms to establish the nunber of species, diversity and equitability of the sample.

In an attempt to define qualitative differences between various sets of samples, I calculated Sanders' (1960) dominance-affinity index for all possible sample pairs. It was obtained by computing the percentage of the total sample represented by each species present in both samples and then suming the smaller percentage for each species. High values of the index indicated faunal homogeneity or affinity between the samples being compared. Portunids were treated in their separate categories.

In order to examine the numerical dominance of species in a series of samples, I used the biological index described by Sanders (1960). The species were ranked $I$ to 7 in each sample and assigned values in reverse order of abundance so that rank of 1 was given 7 points; a rank of 2, 6 points, . . ., and a rank of 7, 1 point. The bioindex value for each species was determined by adding the number of points it scored in all of the samples considered. For example, if a species occurred in 6 samples and ranked first in 4 and second in 2, its index value would be 40 . This index prevents the obvious bias inherrent in ranking species solely by total number of individuals, namely that a species occurring with a low frequency but in large numbers will be rarked above other species present in moderate numbers at most stations. The portunids were treated as a group in this analysis. 


\section{RESULTS}

Numbers of species and individuals and values for diversity and equitability are listed in Table 2. The values for diversity do not appear to contradict a normal distribution, and normality was assumed for statistical treatment of the data. The mean values 2.576, 2.563, 2.328, 2.675, and 2.447 for Areas I, II, and III, and Series S and D respectively gave a nonsignificant F-test after analysis of variance $(F=0.2834$, df $=31)$. Because it could conceivably mask significant differences, the diversity for sample SI ( $\left.\mathrm{H}^{\dagger}=5.110\right)$ was removed by the $\underline{r}$ ratio test for statistical outliers (Dixon and Massey, 1957) before analysis. The regression of diversity on raft volume (Fig. 2) showed that in addition to not changing with season or geographical area, the diversity index did not vary with sample volume. The mean for 33 samples was $2.510 \pm 0.247\left(t_{.05} s_{\bar{x}}\right)$ and the confidence interval on the individual data points ranged from 1.093 to 3.927 ( $t .05 \mathrm{~s}$ ). Variation in calculated diversity values was such that several samples in any one area are needed before a reliable estimate may be made.

Diversity is a function of the number of species, the number of individuals, and the distribution of the individuals among species, i.e. equitability. Numbers of species per sample did not change drastically during the year. Indeed variation was as great within the fall samples as it was throughout the year. In general, within a given set of samples larger rafts tended to hold more species.

The number of individual animals in each sample fluctuated 
Table 2. Number of species and individuals, diversity and equitability of Sargassum samples.

$\begin{array}{lrrrr}\text { Sample } & \text { Species } & \text { Individuals } & H^{\dagger} & E \\ \text { I 4 } & 7 & 60 & 1.9945 & 0.75 \\ \text { I 5 } & 10 & 200 & 2.4565 & 0.83 \\ \text { I 5a } & 14 & 80 & 3.0517 & 0.84 \\ \text { I 6 } & 8 & 82 & 2.8004 & 0.82 \\ \text { II 7 } & 11 & 35 & 3.0927 & 1.10 \\ \text { II 7a } & 13 & 106 & 2.6315 & 0.66 \\ \text { II 7b } & 15 & 140 & 2.5034 & 0.52 \\ \text { II 7c } & 10 & 137 & 2.0110 & 0.53 \\ \text { II 8 } & 18 & 395 & 2.5775 & 0.46 \\ \text { III } & 13 & 480 & 1.8588 & 0.36 \\ \text { III Ia } & 5 & 17 & 1.9903 & 1.05 \\ \text { III 9 } & 10 & 285 & 1.6803 & 0.41 \\ \text { III 9a } & 8 & 98 & 2.4783 & 0.95 \\ \text { III 10 } & 10 & 179 & 3.2723 & 1.38 \\ \text { III 10a } & 12 & 804 & 1.8964 & 0.40 \\ \text { III 10b } & 14 & 730 & 2.4941 & 0.55 \\ \text { III 10c } & 12 & 179 & 2.5322 & 0.66 \\ \text { III 11 } & 18 & 546 & 2.7469 & 0.52 \\ \text { S I } & 19 & 599 & 5.1096 & 2.71 \\ \text { S } & 19 & 266 & 3.3529 & 0.77 \\ \text { S 3 } & 16 & 131 & 2.6495 & 0.54 \\ \text { S 4 } & 16 & 187 & 3.1783 & 0.80 \\ \text { S 5 } & 9 & 47 & 2.7553 & 1.04 \\ \text { S 6 } & 6 & 301 & 1.0270 & 0.41 \\ \text { S 7 } & 9 & 266 & 1.9866 & 0.58 \\ \text { S 8 } & 10 & 80 & 2.1123 & 0.58 \\ \text { S 9 } & 6 & 37 & 1.9064 & 0.82 \\ \text { D I } & 15 & 364 & 2.4978 & 0.52 \\ \text { D Ia } & 18 & 513 & 2.9069 & 0.58 \\ \text { D 2 } & 15 & 505 & 2.2531 & 0.43 \\ \text { D 3 } & 12 & 562 & 1.8550 & 0.39 \\ \text { D 4 } & 16 & 976 & 2.8374 & 0.62 \\ \text { D 5 } & 15 & 1709 & 2.3299 & 0.45\end{array}$




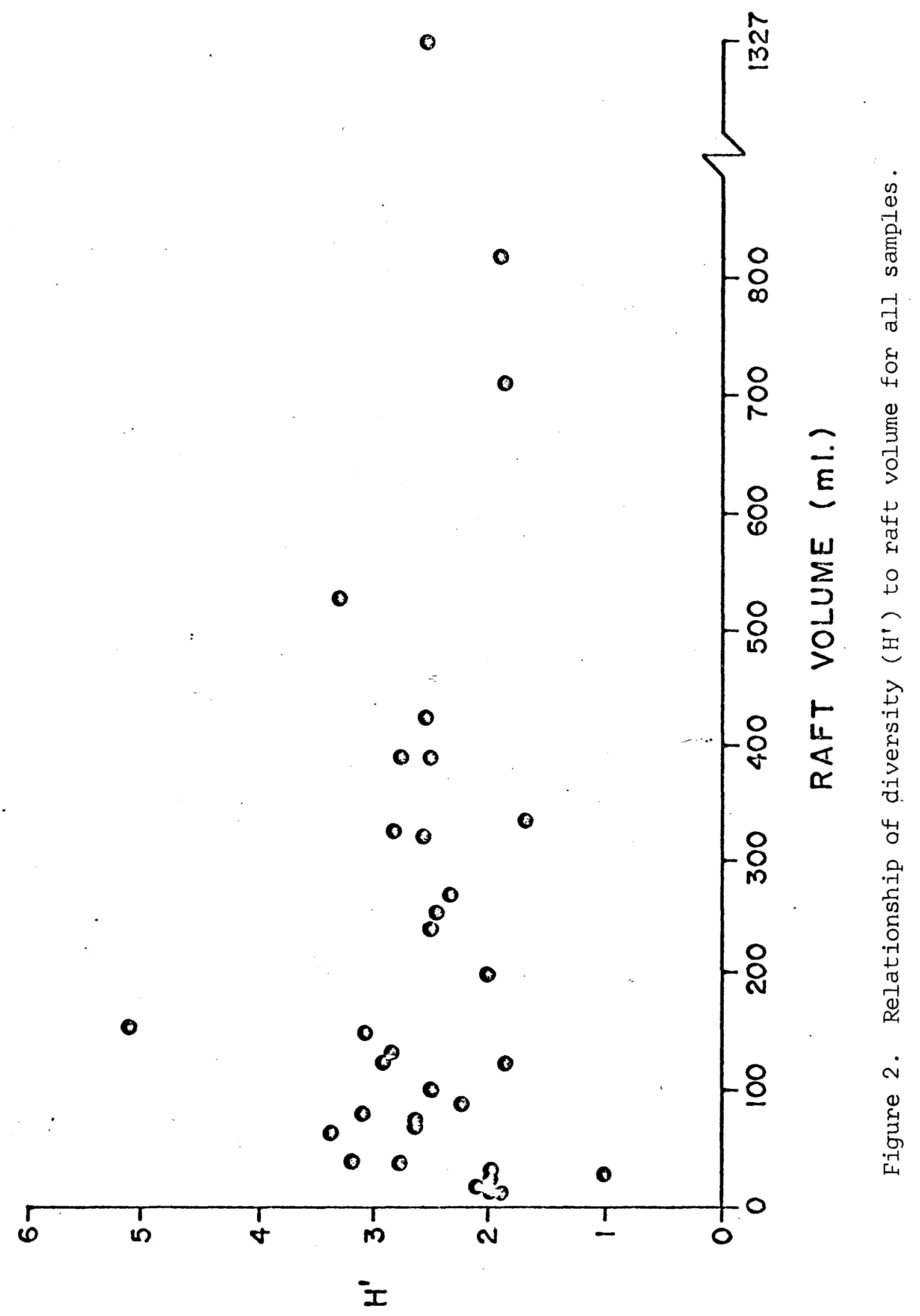


markedly through the year (Fig. 3). Samples from late summer were combined; except fon the larger samples from Area III, the points for the three areas were similar where they shared similar raft volumes. The regression for the spring samples (Series $S$ and D), has a higher slope than the regression for the late summer samples indicating a nore abundant fauna on smaller raft volumes. With one exception (sample SI) the late spring samples had more organisms than early spring, but this is probably accounted for by the larger raft volumes of the $D$ series and not by a change in faunal abundance. Equitabilities were quite variable, ranging from 0.39 to 2.71 . Twenty of the 33 values ranged between 0.50 and 3.00 , with only eight points below and five points above this range. These results indicate a high equitability. They also aid in accounting for some of the extreme diversity values. The prime example occurred at station Sl where an equitability of 2.71, or 2.71 times that predicted by MacArthur's model, is responsible for a diversity of 5.110 with only 19 species. The adjacent station $\$ 2$ with an equal number of species but an equitability of 0.77 had a diversity of 3.353 . At the other end of the scale, sample I2 with 5 species and an equitability equal to 1.05 had a diversity of 1.990 while sample 56 with 6 species and an equitability of 0.41 had a diversity of 1.027 .

The index of dominance affinity is shown on a trellis diagram (Fig. 4) arranged by groups of samples (I, II, III, S, and D). Such a diagram allows one to compare the affinities within an area and the affinities between areas. The mean affinity within Areas I and III was 63.59 and 63.29 respectively. Such values indicate a homogeneous fauna (Sanders, 1960). The mean affinity between samples in Areas I and III dropped to 4I.22, but still denotes a strong relationship 


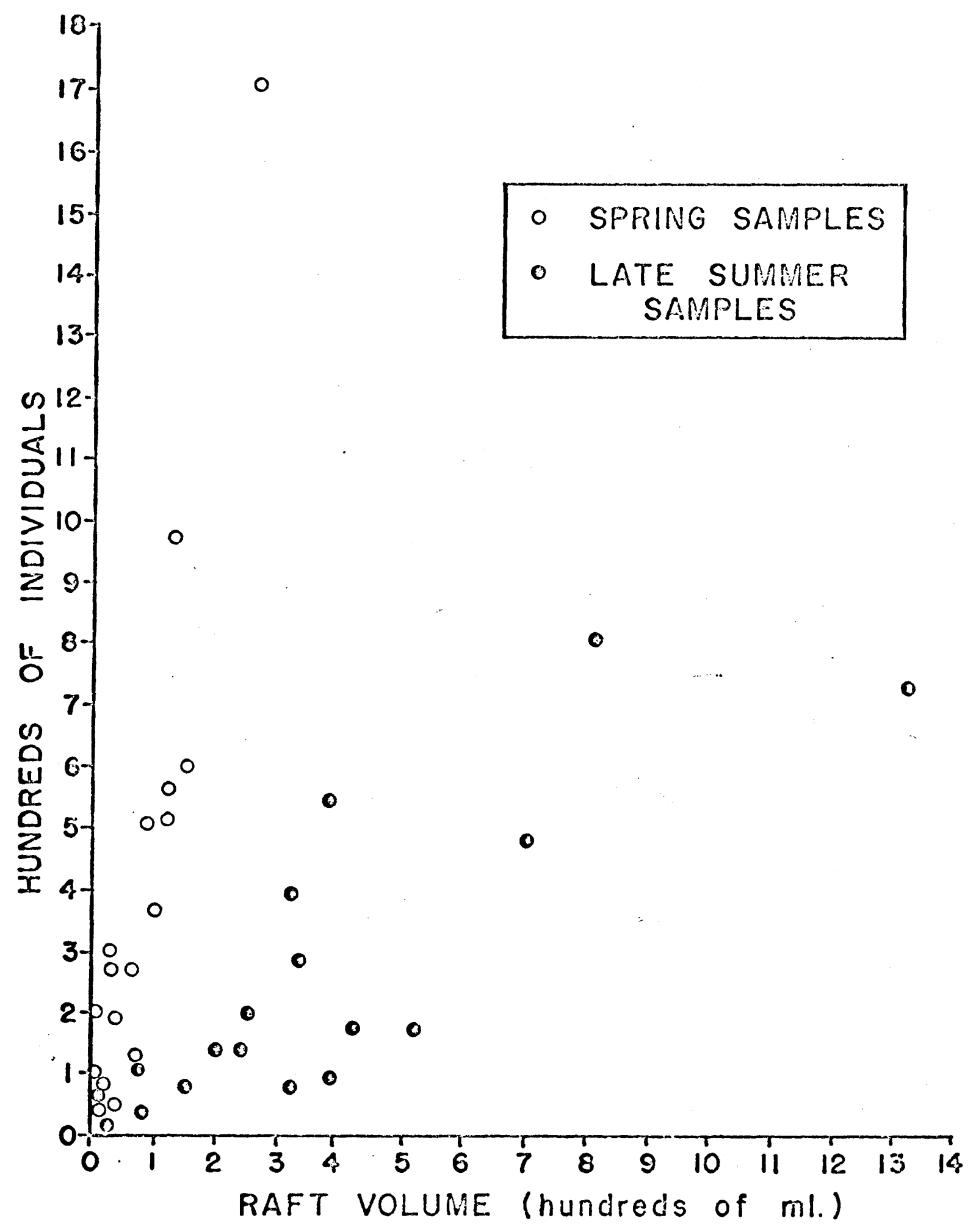

Figure 3. Relationship of the number of individuals to raft volume for samples collected during the spring and late sumner. 


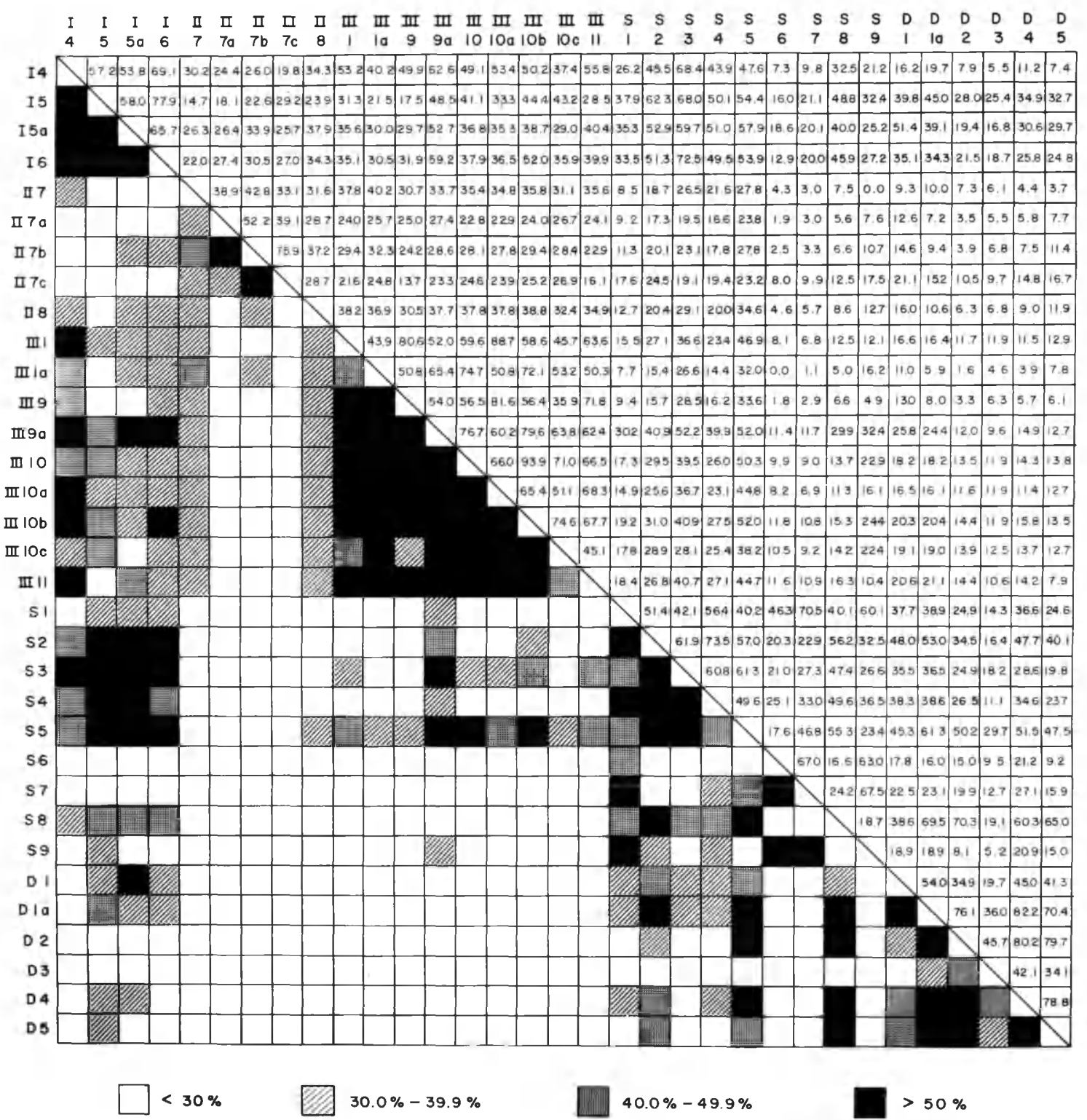

Figure 4. Trellis diagram of the dominance affinity index for all sample pairs. 
between these areas. The affinity within Area II is 40.83 and the affinities between Areas I and II and Areas II and III drop to 26.72 and 29.19. These values demonstrate greater variability in the samples taken offshore from cape Hatteras and a faunal change compared with the bordering regions. The mean within the s series was 43.61 , but this is somewhat misleading because the samples appeared to fall into two groups. Stations 1-5 have higher affinities for each other, comparatively higher raft volumes, and higher diversities than the remaining four samples. A number of taxa, including Gnesioceros, Litiopa, the Nudibranchia, Leander, and Latreutes, are more conspicuously represented in the first five samples. The mean within the D series was 54.68 and compares reasonably with the s series, $\bar{x}=30.70$. Comparisons of the spring and fall samples show some interesting trends:
S: I $\quad \bar{x}=39.46$
D: $I \quad \bar{x}=25.88$
S: II $\quad \bar{x}=14.34$
D: II $\bar{x}=9.51$
S: III $\bar{x}=2 I .82$
D: III $\bar{x}=13.03$.

Series $S$ and Area I had an amazingly high affinity considering the gulf in time and space that separated them. The early spring samples had higher affinities for the late summer samples than did the late spring samples, possibly indicating faunal changes are greater during the summer months than during the winter. In every set of comparisons involving it, Area II had the lowest value.

The species responsible for these affinities are listed in Tables 3, 4, 5, 6, 7, and 8 by decreasing bioindex, abundance and frequency. The one sample from March (RR-20) has not been treated statistically because of its small size and uniqueness. 


\section{DISCUSSION}

Fager (1963) defined a community as a group of species which are often found together. Such a definition tacitly assumes the existence of communities, an assumption frequently made by marine biologists (Fager, 1963; Margalef, 1967; Jones, 1969; Mills, 1969). An opposite viewpoint holds that there are no communities but rather randomly assembled collections of organisms whose ecological tolerance allow them to exist in a particular environnent; each collection is an individual point on a continuum and any grouping of them is, at best, artificial (Fager, 1963). Since an individual Sargassum raft is discrete within the surrounding planktonic environment, and is populated by a sharply different fauna, it is best treated as a separate community.

Communities have often been named by dominant animals (biocenosis), substrate type (biotope), or by a combination of the two (Jones, 1969). Recently, ecologists have not felt the need for a specific name, which may be misleading, and have typified communities by groups of recurring organisms (Fager, 1963; Margalef, I'967; Jones, 1969). However, I don't feel overly anachronistic in designating the weed complex as the Sargassum community. As well as being the substrate, the alga is the most obvious organism in the community.

A small raft of algae afloat on the Atlantic Ocean is a rather extreme habitat. One would expect relatively fewer species on these biotic islands than in the deep sea benthos beneath them (Sanders, 
1968). This situation is reflected in the diversity, which averaged 2.510 bits of information per individual. Although comparisons of diversities of different communities and different habitats are extremely risky, I will attempt two such comparisons to give the reader a basic frame of reference. Grassle (1967) found diversities ranging from 4.023 to 5.083 from grabs on the North Carolina shelf and slope sieved to include meiobenthos. Diversity values for Sander's (1960) study of Buzzard's Bay, Massachusetts as given by Grassle, varied between 1.558 and 3.466. Although the Sargassum community has a tropical affinity and a benthic origin somewhere in the distant past, it has a lower diversity than a tropical benthic habitat.

Considering the uniqueness of the habitat and the number of species encountered, the weed community is remarkably diverse. High diversities were supported by the equitable distribution of the fauna. Lloyd and Ghelardi (1964) hypothesized that the equitability component of diversity is sensitive to the stability of the physical conditions. Indeed, physical conditions were stable: temperatures ranged between 22 and $28^{\circ} \mathrm{C}$, Sargasso sea salinities are high and constant, and dissolved oxygen at the ocean surface should approach saturation. Another factor promoting high diversity is the low productivity of the Sargasso sea, which has been frequently labeled an oceanic desert. Margalef (1968) indicated an inverse relationship between productivity and diversity, reasoning that rich conditions, such as those in a plankton bloom, will favor those few species maximally adapted to utilize the situation.

Among the many theories explaining high diversity, stability is the most widely accepted (Piankā, 1966). Time by itself does not 
automaticaliy permit a community to diversify, but it is certainly part of the stability theory. In this light it is interesting to note that Markkaveeva (1965) found 10 species on Sargassum vulgare afloat in the Red Sea which also occur on pelagic Sargassum in the Atlantic. This finding indicated that the floating community is old, probably extending back to the time when the Tethys sea existed.

The dominance affinity index within the individual series of samples was remarkably high when one considers that the weed floats on the water surface, the most variable part of the sea. There is no doubt that the weed forms the basis of a community and not a haphazard congregation of individuals. The change in fauna evident in Area II may have resulted from a prolonged residence within the area. The gyre, adjacent to Cape Hatteras but inshore from the Gulf Stream (Harrison, Norcross, Pore, and Stanley, 1967), may have trapped the Sargassum where it could be modified by the local fauna. Affinities within the late spring samples show a similarity between the Sargassum community in the Gulf Stream and in the Sargasso Sea.

Dominance varied among the samples, and I would consider only the polyclad Gnesioceros sargassicola, the polychaete Platynereis dumerilii, the snail Litiopa melanostoma and the shrimp Latreutes fucorum as having maintained dominant positions in each series of samples. Many of the species showed seasonal peaks of abundance. The anemone Anemonia sargassensis was only abundant in the late winter and early spring collections. By late spring it had disappeared in all but one sample. Nudibranchs were most abundant in the spring. The Lepas barnacles also had a peak abundance in late winter and early spring. Lepas pectinata was the only abundant species; it did not occur in association with $\underline{L}$. anserifera as 
reported by Pilsbry (1907). Amphipods exhibited several types of seasonal distribution. Hemiaegina minuta, the only caprellid found, was a dominant in both spring series. Sunamphitoe pelagica was a dominant in late spring, the only time it was collected, while Biancolina sp., a form which normally burrows into algae, had a maximum abundance in early spring although it was taken twice in late spring samples. Ampithoe longimana and Atylus minikoi were taken in late sumner in the Hatteras area. The isopod Janira minuta was the dominant organism in late spring, but was also abundant in early spring and late summer in Area I.

The pycnogonid Anoplodactylus petiolatus reached peak abundance in the late spring but was present in every set of samples. Timmermann (1932) found most of his Anoplodactylus in the central or eastern part of the Sargasso sea. My observations show they can also be abundant in the western part of the sea and in the GuIf Stream. Although Timmermann frequently encountered Endeis spinosa, I found only a single individual. Hedgpeth (1948) took Tanystylum orbiculare from gulf-weed cast ashore on the Gulf coast of Texas. I found only Il individuals in two neighboring early spring samples.

The portunids in the late summer samples were necessarily treated as a group, certainly elevating their position above that which an individual species could claim. Since most of the species were probably transients sharing similar niches, such treatment is not unjustified. Only Portunus sayi is commonly considered a resident of the community. The abundance of megalopa and juveniles (including dromiid megalopa) indicates that the weed might offer a protective advantage to the planktonic young. Williams (1965) lists the range of the portunid, crorius ruber as from South Caroina to Rrizil. 
Cronius juveniles taken in the Virginian province probably represent a range extension for this species.

Planes minutus, a grapsid crab typically associated with Sargassun was rare or absent, except in late spring. The first two samples from the Gulf Stream had four Planes while the remaining four samples from the Sargasso sea had 30. Coincident with this, was the disappearance of $\underline{P}$. sayi from Sargasso sea samples. Although both species occur in both localities, it is possible that Planes has a more pelagic distribution while Portunus remains closer to shore. The shrimp Leander tenuicornis was dominant only in Area III, though it was present in other series in low numbers.

Juvenile fishes were found chiefly in late summer in Areas II and III. Stephanolepis hispidus was the dominant animal in Area II. These juvenile filefishes lead a pelagic life, but associations with the weed remain transitory because the fishes leave for the bottom when between 50 and $100 \mathrm{~mm}$ in length (Berry and Vogele, 1961). Predation by these fishes in Area II may have been partially responsible for the different faunal homogeneity. Seven of the eight other species of juvenile fishes were found in Area III, indicating a tropical affinity. The pipefish Syngnathus pelagicus is a typical resident, but the other species were transients probably attracted to the weed for protection (Gooding and Magnuson, 1967). The Sargassum fish Histrio histrio was found only in late spring though Adams (1960) took it year round.

Regarding seasonal and locel variation, this study has perhaps raised more questions than it has answered. I have no sure way of knowing if seasonal changes I observed were the result of real periodicity of the fauna on whether changes were due to variations 
within the great gyre of the sargasso sea. In other words geographical. variation within the gyre could be taken for seasonality because of sampling in one place at different times of the year. To rectify this situation and definitively establish spatial and temporal variation within the Western North Atlantic would require simultaneous sampling over many sections of the Sargasso sea and the Gulf of Mexico, as well as repeated sampling over a several year period at selected stations. 


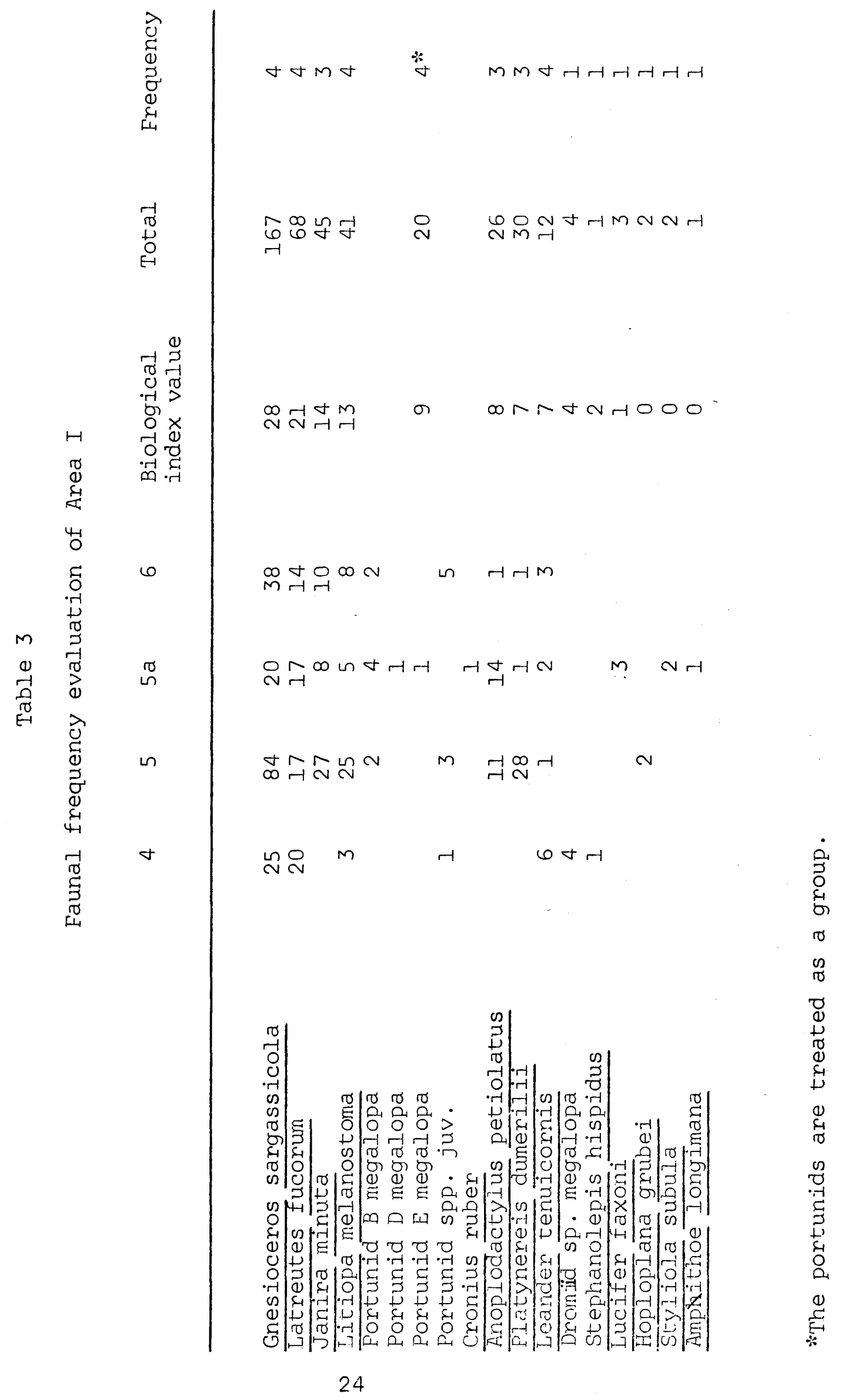




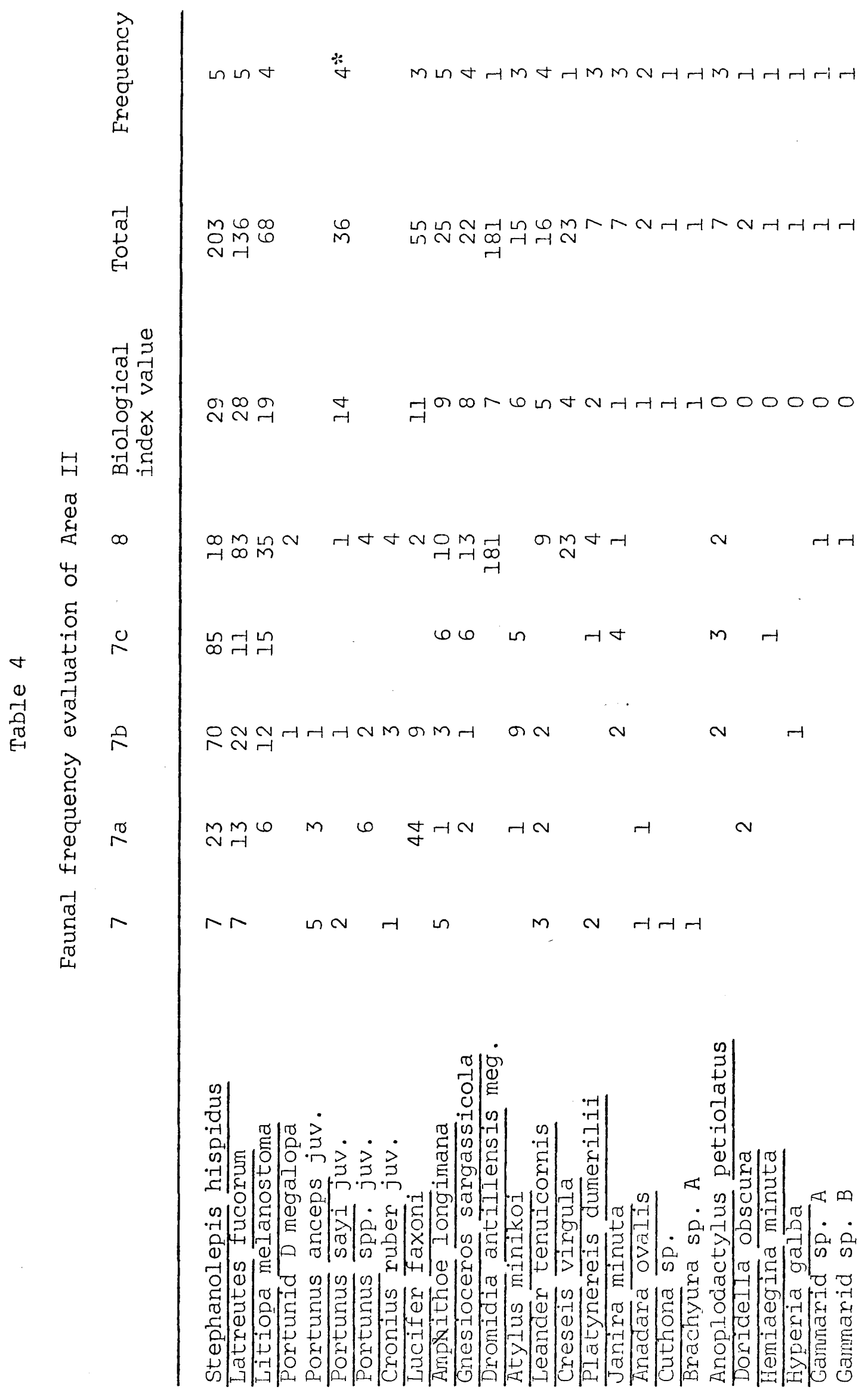




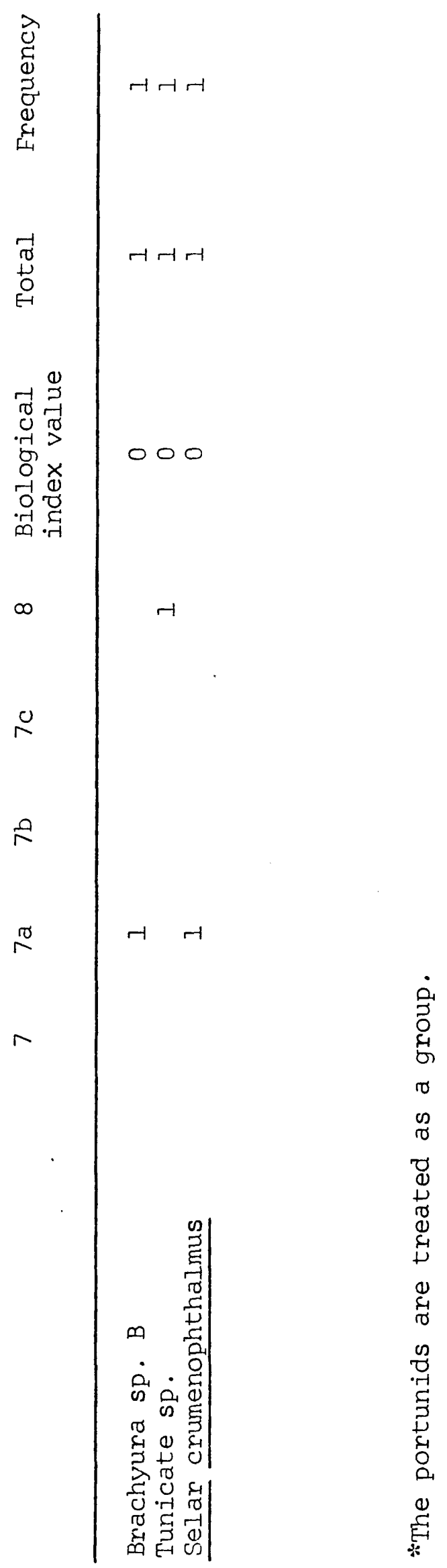




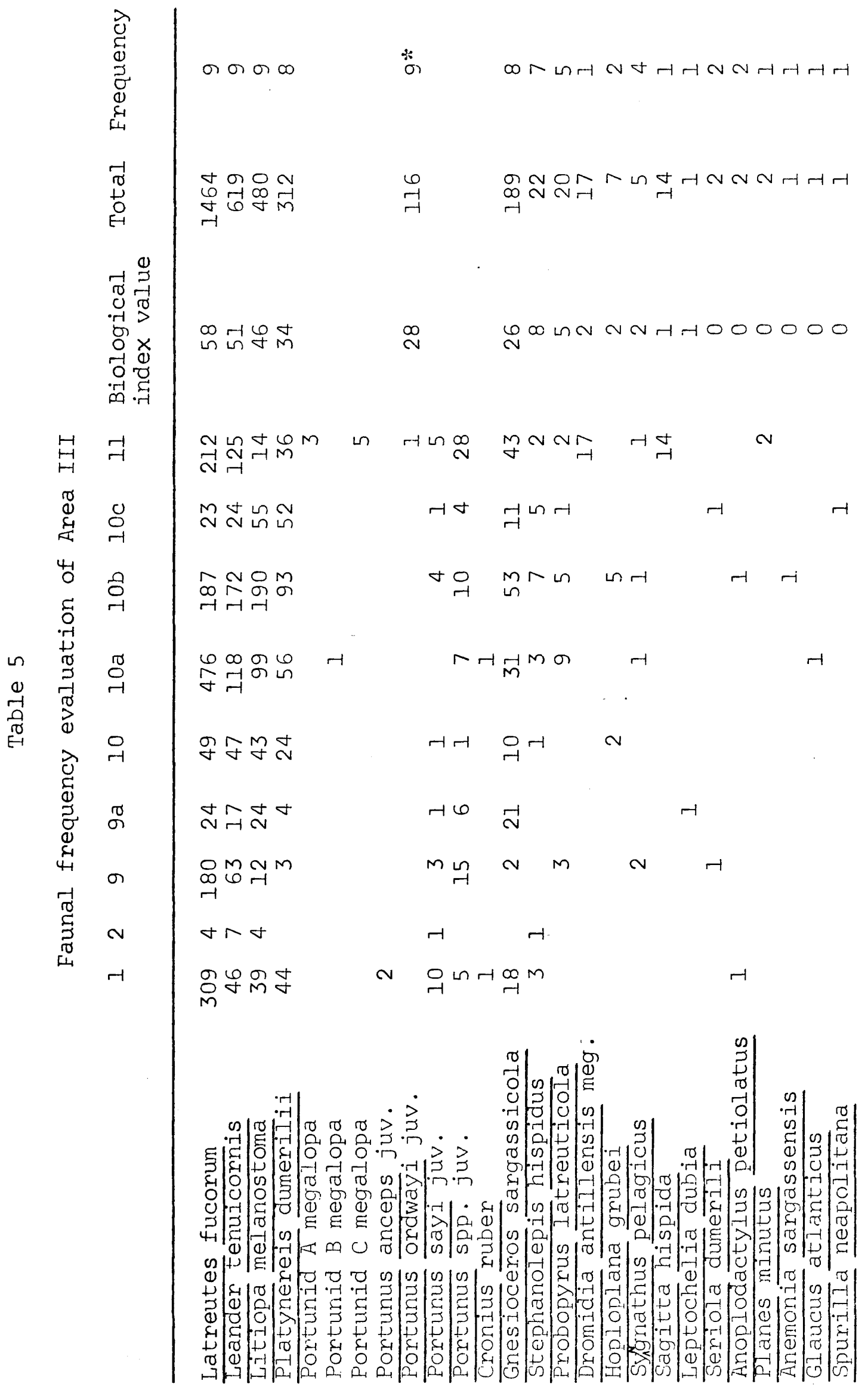




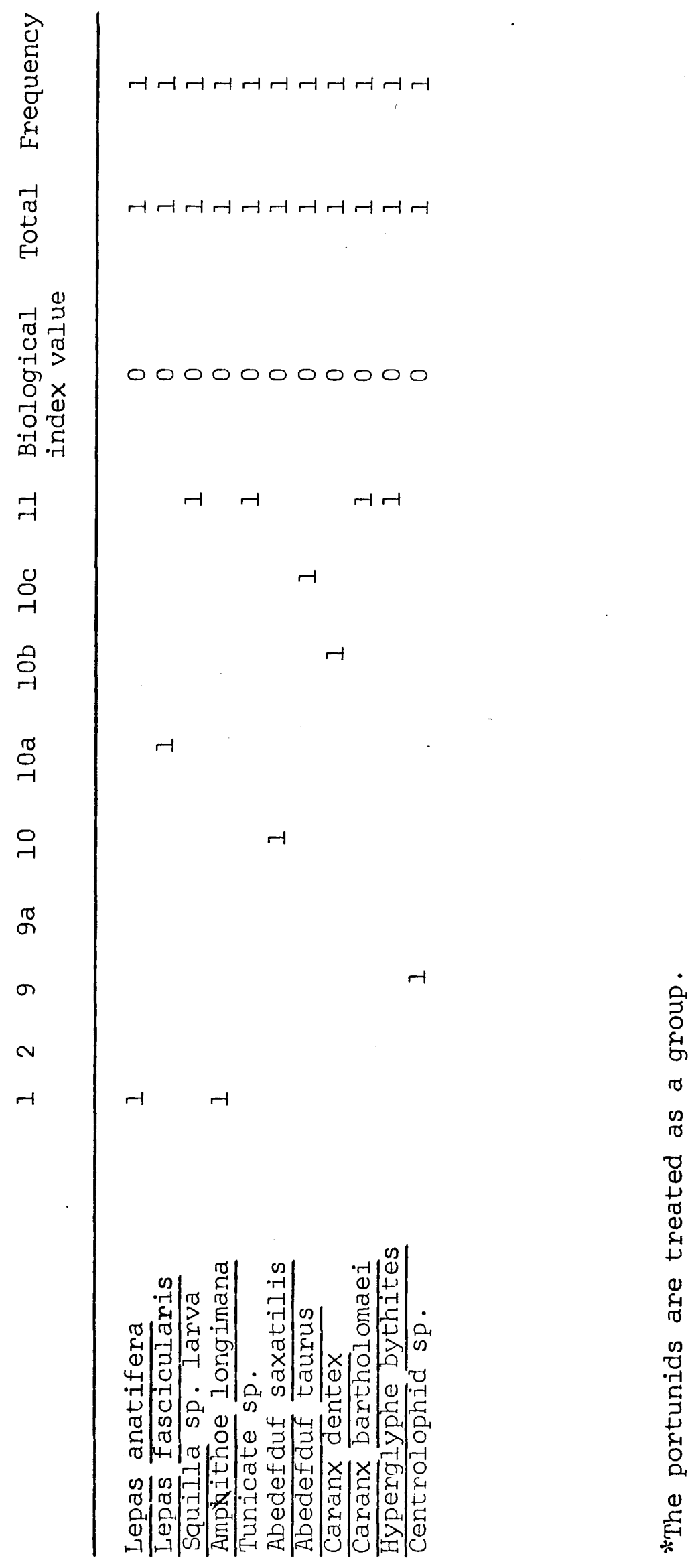


Table 6

Faunal frequency evaluation of $R R 20$

Lepas pectinata

91

Anemonia sargassensis

45

Gnesioceros sargassicola

2 


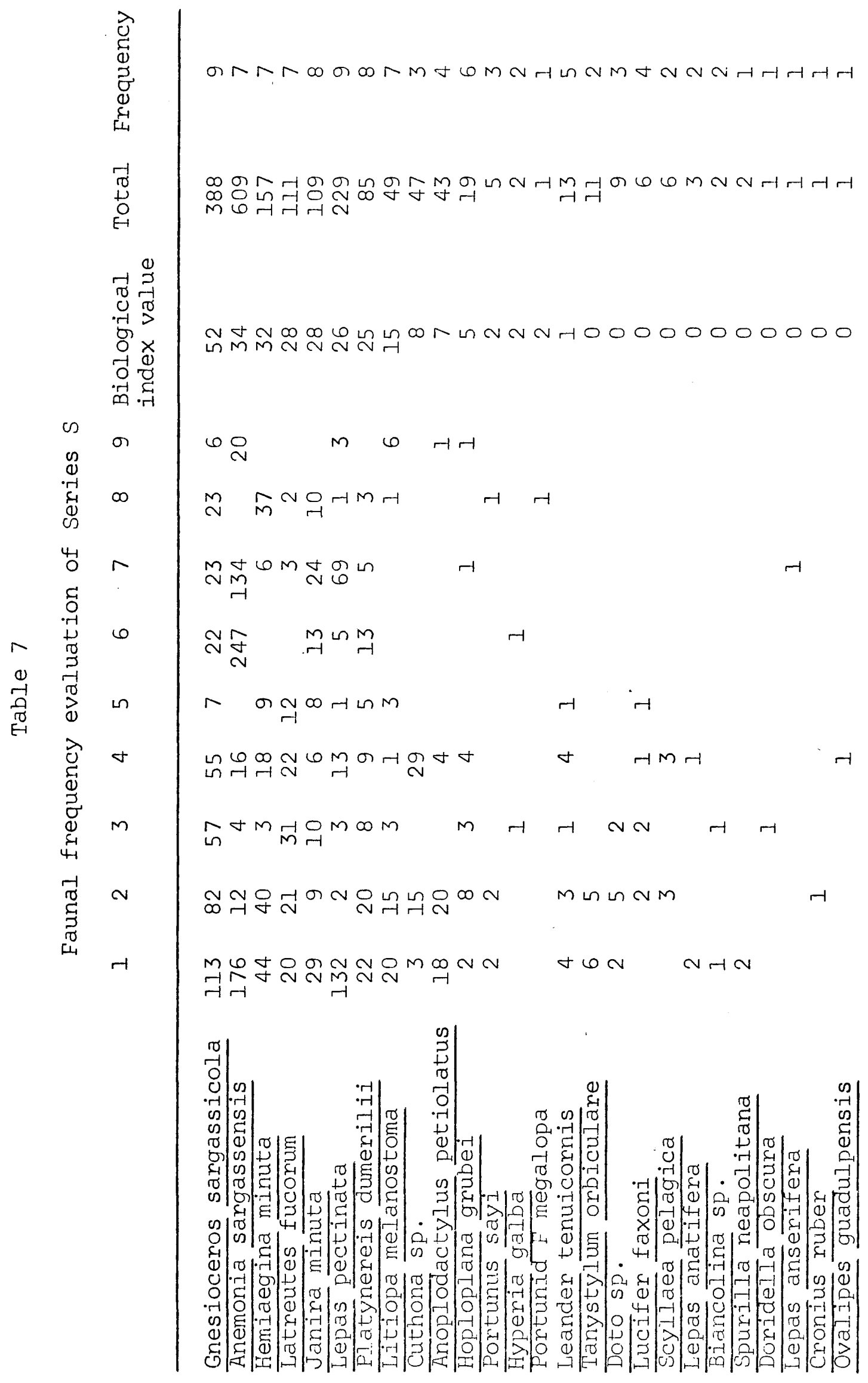




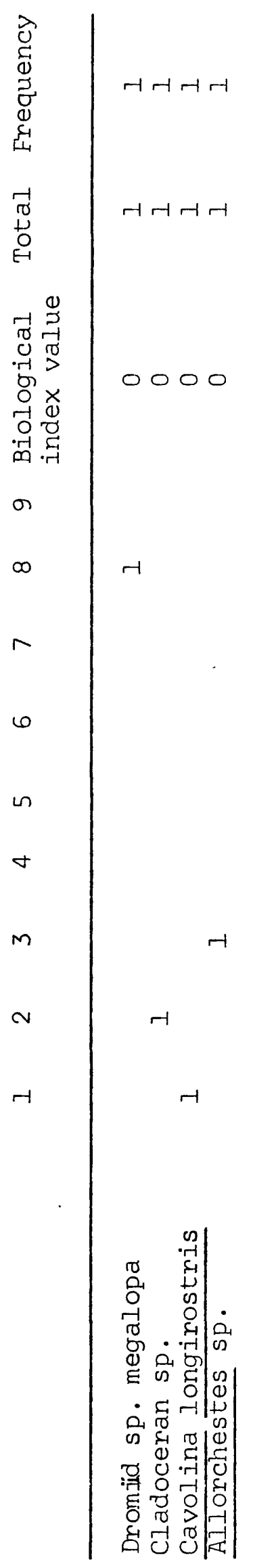




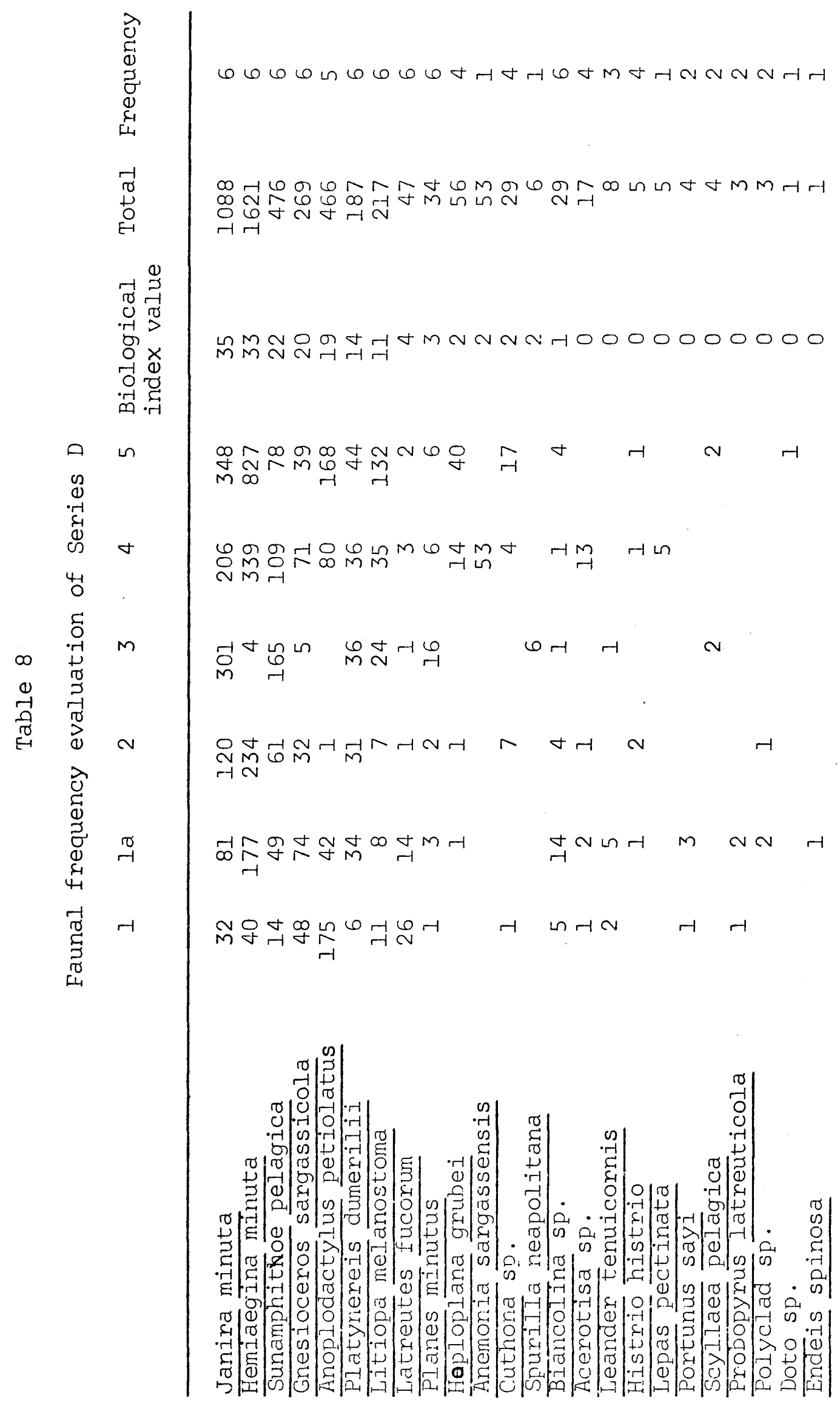




\section{LITERATURE CITED}

Adams, J. A. 1960. A contribution to the biology and postlarval development of the Sargassum fish, Histrio histrio (Linnaeus), with a discussion of the Sargassum complex. Bull. Mar. Sci. 10:55-82.

Berry, F. H., and L. E. Vogele. 1961. Filefishes (Monocanthidae) of the Western North Atlantic. U. S. Fish Wildl. Serv., Fish. Bull. 61: 61-109.

Conover, J. T., and J. McN. Sieburth. 1964. Effect of Sargassum distribution on its epibiota and antibacterial activity. Bot. Marina 6:147-157.

Deacon, G. E. 1942. The Sargasso Sea. Geogr. J. 99:16-28. Dixon, W. J., and F. J. Massey, Jr. 1957. Introduction to statistical analysis. McGraw-Hill Book Company, Inc., New York. 488 p. Fager, E. W. 1963. Communities of organisms, p. 415 to 437 . In M. N. Hill (ed.) The sea. Vol. 2. Interscience, New York. Gooding, R. M., and J. J. Magnuson. 1967. Ecological significance of a drifting object to pelagic fishes. Pacif. Sci. 21:486-497. Grassle, J. F. 1967. Influence of environmental variation on species slope. Unpublished Ph.D. dissertation. Duke Univ., Durham, North Carolina.

Harrison, W., J. J. Norcross, N. A. Pore, E. M. Stanley. 1967. Circulation of shelf waters off the Chesapeake Bight. Surface and bottom drift of continental shelf waters between Cápe 
Henlopen, Delaware, and Cape Hatteras, North Carolina, June 1963 - December 1964. Environ. Sci. Serv. Admin. Prof. Paper 3: $82 \mathrm{p}$.

Hedgpeth, J. 1948. The Pycnogonida of the Western North Atlantic and the Caribbean. Proc. U. S. Nat. Mus. 97:157-342.

Hentschel, E. 1922. Ueber den Bewuchs auf den treibenden Tangen der Sargassosee. Mitteil. Zool. Mus. Hamburg 38:1-26.

Ida, H., Y. Hiyama, and T. Kusaka. 1967. Study on fishes gathering around floating seaweed. II. Behavior and feeding habit. Bull. Jap. Soc. Sci. Fish. 33:930-936.

Jones, G. F. 1969. The benthic macrofauna of the mainland shelf of Southern California. Allan Hancock Monogr. Mar. Biol. 4:2l9 p. Krümel, O. 1891. Die nordatlantische Sargassosee. Petmanns Geogr. Mitteilungen 37: 129-141.

Lloyd, M., and R. J. Ghelardi. 1964. A table for calculating the equitability component of species diversity. J. Anim. Ecol. 33: $217-225$.

Lloyd, M., J. H. Zar, and J. R. Karr. 1968. On the calculation of information-theoretical measures of diversity. Amer. Midl. Nat. 79: 257-272.

MacArthur, R. H. 1957. On the relative abundance of bird species. Proc. Nat. Acad. Sci. 43:293-295.

Margalef, R. 1967. Some concepts relative to the organization of plankton. Oceanogr. Mar. Biol. Annu. Rev. 5:257-289.

Margalef, R. 1968. Perspectives in ecological theory. University of Chicago Press, Chicago. $111 \mathrm{p}$.

Markkaveeva, E. B. 1965. The biocenosis of sargasso algae in the Red Sea [in Russian]. Bentos. Nauk, Dumkā: Kiev, p. 81-93. 
Mills, E. L. 1969. The community concept in marine zoology, with comments on continua and instability in some marine communities: a review. J. Fish. Res. Bd. Canada 26:141.5-1428.

Murray, J., and J. Hijort. 1912. The depths of the ocean. MacMillan and Co., Ltd., London. 821 p.

Parr, A. E. 1939. Quantitative observations on the pelagic Sargassum vegetation of the Western North Atlantic. Bull. Bingham Oceanogr. collect. 6: 1-94.

Pianka, E. R. 1966. Latitudinal gradients in species divensity: a review of concepts. Amer. Nat. 100:33-46.

Pilsbry, H. A. 1907. The barnacles (Cirripedia) contained in the collections of the U. S. National Museun. U. S. Nat. Mus. Buli. 60: $122 \mathrm{p}$.

Prat, H. 1935. Remarques sur la faune et la flore associees aux Sargasses flottantes. Le Nat. Canada 62:120-129.

Sanders, H. Is. 1960. Benthic studies in Buzzards Bay. III. The structure of the soft-bottom community. Linnol. Oceanogr. 5: $138-153$.

Sanders, H. L. 1968. Marine benthic diversity: a comparative study. Amer. Nat. 102:243-282.

Shannon, C. E. 1948. A mathematical theory of communication. Bell Syst. Tech. J. 27: 379-423, 623-656.

Sieburth, J. McN., and J. T. Conover. 1968. Sargassun tannin, an antibiotic which retards fouling. Nature 208:52-53.

Thomson, C.W. 1878. The voyage of the Challenger, the Atlantic. Vol. 2. Harper and Brothers, New York. 340 p. Thulin, G. 1942. Ein neuer marinen Iardigrad. Goteborgs Kungl. Vetenskaps. Vitternets Samh. Handl. 2(5):1-10. 
Timmenmann, G. 1932. Biogeographische Untersuchungen uber die Lebensgemeinschaft des treibenden Golfkrautes. Z. Morphol. Oekol. 25:288-335.

Weis, J. S. 1968. Fauna associated with pelagic Sargassum in the Gulf Stream. Amer. Midl. Nat. 80:554-558.

Williams, A. B. 1965. Marine decapod crustaceans of the the Carolinas.

U. S. Fish Wildl. Serv., Fish. Bull. 65:1-295.

Winge, $"$ O. 1923. The Sargasso sea, its boundaries and vegetation.

Rep. Danish Oceanogr. Exped., 1908-1910. 3(Misc. Papers No. 2): $34 \mathrm{p}$

Woodcock, A. H. 1950. Subsurface pelagic Sargassum. J. Mar. Res. $9: 77-92$.

Yeatman, H. C. 1962. The problem of dispersal of marine littoral copepods in the Atlantic Ocean, including some redescriptions of species. Crustaceana 4:253-272. 